\title{
Changing the Image of Scientists among College Students in Israel
}

\author{
Bar Varda 1,*, Pasit Koren², Edna Rubin ${ }^{3}$, Anne Gail Buck ${ }^{4}$ \\ ${ }^{1}$ Science education department, Hebrew university of Jerusalem \\ ${ }^{2}$ Israel Education ministry instruction and curriculum design \\ ${ }^{3}$ Achava Teacher College \\ ${ }^{4}$ Curriculum and Instruction Department, Indiana University Bloomington \\ *Corresponding author: barvarda@zahav.net.il
}

Received October 22, 2013; Revised November 09, 2013; Accepted November 17, 2013

\begin{abstract}
With this study, we sought to address some deficiencies in the image of scientists held by pre-service teachers in Israel. These include a few concerns for women scientists, as well as a lack of understanding about fieldwork and contemporary scientific equipment. The study was carried out with two groups of pre-service science students, mostly women. It was done through interference: following the web, meeting with experts and constructing leaning materials for pupils by the participants. Research was in the form of one strand research using qualitative methods. During the research, the image of women scientists changed considerably. Pre interference views were: there are no women scientists and physics and astrophysics are not for women. Women scientists were described as torn between family and work. In the post interference stage, a high appreciation for women scientists and their work in all domains was observed, woman scientist were portrayed as relaxed, taking part in team work, doing field work, and using specialized sophisticated equipment.
\end{abstract}

Keywords: scientist image, college students, active involvement, conceptual change

Cite This Article: Bar Varda, Pasit Koren, Edna Rubin, and Anne Gail Buck, "Changing the Image of Scientists among College Students in Israel.” American Journal of Educational Research 1, no. 9 (2013): $396-405$. doi: 10.12691/education-1-9-8.

\section{Introduction}

Research has revealed that women remain very poorly represented in the image of scientists held by college students in Israel. A summary of former research supports this statement [1,2,3]. In this former research, women were hardly mentioned as scientists: only about $7 \%$ of the drawings were of women and among scientists' suggested names women appear at about $7-8 \%$ of the lists. Only one or two women were mentioned for each group of about 100 undergraduate students [1,2]. Captions and free writings in several groups referred to the scientist as a man ("the white mail with the lab coat and goggles"). This information was collaborated by the reasons given for not becoming a scientist, such as "being a scientist causes harm to the family", mostly attributed to: "the woman needs to stay at home and take care of her family". Early marriage and other traditional customs in Israel were also mentioned [1]. Some of these reasons were heard mostly among participants coming from religious groups, but were also found among secular pre-service student teachers. Properties attributed to the scientist were: being intellectual (clever, wise), dedicated and diligent: "working long hours in the lab doing experiments"; lonely: "does not spend time with friends and not with his family". Other properties attributed to the scientists were remote, objective and creative. Students said that these properties are typical to males [4]. Drawing captions and essay writing gave the participants a chance to express their views freely and not as answers to forced suggestions revealed their true views. Open tools reinforced the data of the closed tools such as draw, names and properties. A survey of sources of knowledge used at school, about men and women scientists, revealed a deficiency of women names; women scientist are less mentioned than male scientists in science text books and other leaning materials used by the pupils of the future teachers [1]. There is a gap between women and men especially regarding prestigious occupation, such as leadership, command, management, science and medicine, and also concerning sport, religion and army, when the ratio of women to men is one to four. The male is characterized as outgoing, creative, taking part in many occupations among them science, and possessing the role of a leader. Women are still depicted as performing house hold chores. The positive properties attributed to men in those text books, are being strong, diligent, accurate, intelligent similar to the properties attributed to scientists [1,5]. The students noted these properties when describing why women are not willing or not able to be scientists. Limited knowledge about women's roles in science, and the lack of women role models in science, might explain the lack of motivation of women to work in science $[3,5,6]$. 
In light of these results, an intervention was designed with the goal of changing pre-service teachers' images of scientists by involving them in the preparation of a learning unit about women scientists. This experiment was made since several investigators stressed that a change in views could be made only through active engagement in preparing leaning materials [7]. It is also based on the idea that students should be surfaced to the work active scientists $[8,9,10]$ emphasized the differences between the researchers concerning their attitudes about the way teaching methods affect their pupil. The views of the teachers about science and scientists do not always appear in the class and do not affect the learners. As found [4] issues that concern science and scientists interest only a small group among the pupils, those who have high level of attitudes towards science in general. There is a complicated interaction between the views of the teacher and their influence on the pupils' experiences, knowledge, intensions and constraints. Disciplinary and other knowledge of teacher does not always appear in the class. But, on the other hand, if the teacher is not acquainted with a given domain, such as women scientists, women will not be mentioned in the class, and will not serve as role models to these classes. Encouraging students to extend their knowledge about women scientists is therefore recommended. The stereotypical perception of a scientist as a man wearing the white lab coat and spending all day doing chemical experiments with beakers and test tubes are related to a lack of understanding about the diversity of scientific research fields. Addressing students' understandings of scientific inquiry and the role of women among the scientists is intimately related to their understandings of scientists.

\section{Theoretical Background}

The problem regarding women scientists is connected to the general problems of motivation to learn science. Institutions for education need to educate experts in science and technology, since research plays a central major role in the society. Women cannot be excluded from science. Assuring this can be done by increasing appreciation for women scientists; through exposing women as role figures in science, meeting with women scientists experts, and learning about modes of science more fit for women $[4,5,6]$. More science students, among them women science students, are needed in the teacher colleges to train the coming generation, since people need specialization in order to gain access to the labor market.

Mass communication (print and broadcast media) influences people's experiences and shape people's perception of oneself and one's surroundings. Images that initiate from the media affect students' ideas, and motivate or discourage them towards science. Services are symbolizing status and identity. People are increasingly seen as consumers, in public services and citizens' roles as patients, clients, students and electorate [4]. This trend encouraged technology, when technology education is needed for training useful and caring consumption. Effects of consumption on environment and society are domains in which women are interested [4] they should be engaged in science learning. Conflict between those needs and the small reference to women scientists emerges from the findings of the previous research.

\subsection{Changes in the Society and the Motivation to Participate in Science}

Consequences pro and against learning science initiate from the changes in society. Currently, classical structures have a weakened function in some western secular societies. In these societies, people must to a larger extent define and construct their identity and their biography by themselves. Traditional ways are weakened, concepts form rapid changes, and facts can be temporary, incomplete and object for debate, traditions and authorities have lost some credibility. This leads people to question the credibility of the established traditions and truths that are passed down from authorities and older generations (called grand narratives). Scientists, teachers and parents have a weakened function in beliefs, choices and actions. The certainty of knowledge; even knowledge from the core domains of the natural sciences are questioned and willing to learn science and believe the learned is weakened. Through new information and communication technologies people have access to larger amounts of information; they experienced the untrustworthiness of scientific discoveries and theories [11]. People know that information may be temporary this make people less convinced about prevailing 'truths' and 'facts'. Science is though appreciated for its impact on life in the form of technological uses [4]. Traditional societies question the truth of science, but they accept the truth of the narratives of their own authorities without questioning [2]. Even if people are less convinced about prevailing truths and facts, they are still interested in the ways science and technology affects them. This leads to a new way to estimate science and tendency to move towards more applied domains, with topics that fit women [6].

The Processes described above lead to individualization when the society accentuates the individual's freedom and independence. The individual is the unit in the society; partially liberated from collective structures, and feels that her/his life has a range of possible ways ahead. S/he must make the choice by her/himself, and take the responsibility for the consequences. Sex roles and family effect change, and new demands and constraints are imposed on individuals [12]. As traditions, authorities and grand narratives play smaller roles, the individual has to consider and choose for her/himself identities regarding learning and future career as self-definition [4]. Women may adopt career in science or as science teachers, but social interactions affect their identity construction; since the individual acts within given society. Women college students also create identities for themselves and construct their attitudes towards science within it. In the following, arguments of women against being scientists as contradicting their identity will be discussed since their individualistic as well as social identities have conflicting attitudes toward science. The individualistic view is though not extreme in our country (Israel) general society, and especially in the traditional one; that took part in the research [1].

\subsection{Model for Conceptual Change}

The conflict described above was addressed through conceptual change. The line of intervention applied in this research followed the idea that teaching should be guided by educational research [4]. Lines of research that 
provided evidence for activities that effect student's attitudes towards the image of the scientist and could improve it, were adopted here to make the set of interventions that were used. Insights were drawn from research on students at varying ages, about the image of scientists and interventions that changed it $[3,5,6,13,14,15]$. Intervention was reinforced by the use of conflict situations following the social constructivism [16]. The principles of the constructivism applied in this project are as follows: People have their own conceptions regarding each concept (in this case about the image of the scientist). These concepts were initiated from views common to their society, books, media and instruction. These concepts are well entrenched and it is hard to change them. The process of change consists of several stages [17].

\subsubsection{Testing}

The existing views of pre-service teachers about the image of women scientists were sought. This stage provided information about the students' individual as well as social attitudes towards science. This information was collaborated with the results of previous research regarding the images of science and scientists that showed that women are rarely mentioned as scientists.

\subsubsection{Exposition and Reflection}

The students were exposed to their existing views. Students were provided with opportunities to reflect on their ideas and share ideas with their mates.

\subsubsection{Creating a Conflict}

By providing the learners with information contradictory to their views, we sought to create a conflict. Realizing the conflict the students were ready to move to the consecutive stage.

\subsubsection{Extending}

By revealing the conflict, we set the stage for the students to extend and deepen their knowledge; thus, encouraging them to build and establish new concepts. This extension of knowledge was carried out through the active involvement of the students through a web search, meetings with active scientists in their research places, conversations with scientists, and the creation of learning units dealing with women's contribution to science.

\subsubsection{Sharing}

The new knowledge was shared with the whole group to demonstrate the changed concepts.

\section{Methodological Approach}

Researchers has shown that trials to change the attitudes of learners regarding the nature of science and the image of the scientist through the use of conventional tools [18], and as a consequence of making change in the curriculum [19] are often not successful. Active involvement in the creation of learning materials makes the knowledge more significant to those who take part in its creation and confirmed as a better way to change their views [7]. This method addresses the student's individuality and their self image as women and college students. Knowledge about the enterprise of scientists, male and female as well, will give students and pupils role models of women to identify with, and will improve their views about the scientists in general [5,6,8,9]. This design is based on the constructivist approach to the teaching of science as formulated by $[16,17]$. New concepts and attitudes are constructed by active involvement: experimenting, writing, discussion. New understanding and attitudes were created and manifested by applying them in changing situations. An essential part of the learning was thinking and reflecting on their activity [20,21] during discussions conducted between the learners and between the learners and teacher deepened their understanding.

\subsection{Participants}

The project of building the leaning units was carried out during a course about science and scientists in classes of pre service science teacher students learning science in a teacher college. Secular students were at their second and third year of their college most of them women. The sample consisted of 20 participants: 19 women, one man. The age range of these participants was 21 to 37 years. Traditional class consisted of 25 females of third year preparing to be general and science elementary teachers. The small sample reflects the minority of science pupils, especially male students, among pre service student teachers, a situation that might be rectified through this and similar projects. The projects were conducted within a course of four weekly hours to students who qualify to science teaching at the elementary and junior secondary school. This one year course contained 122 hours, 56 of them were dedicated to the project. Other part of the course dealt with alternative conceptions and reflection upon them. This knowledge helped students to reflect on their own notions regarding the image of the science and scientists.

\subsection{Intervention}

The stages of intervention follow the model of [17] described before.

\subsubsection{Testing and Exposition, Surfacing}

A pre survey about the image of the scientist was carried out among the participants of the group. The tools used were similar to those found in general former research including our previous research [1]. It was intended to cause awareness of the participants to their own ideas to be used in the reflection stage. Survey consisted of the tools: Names of scientists: Give a list of five names of scientists. Draw a scientist: Draw a scientist at work -DAST. Short Answers: What are your sources of knowledge about scientists? Do you fill that you can be a scientist? Do you want to be one? Why or why not? Properties of scientists: List the properties you attribute to scientists. Essay: Write a short essay about a day in the life of a scientist: a man and a woman.

The pre-service teachers were provided with a cumulative report of the survey packet and asked to reflect on the images and ideas that were revealed. These findings were used in the next steps of the intervention.

\subsubsection{Creating a Conflict}

An investigation through the internet web aimed at finding out if women scientists exist, how many women 
can be found? In what fields they work and the research fields that they do not have part in. The findings of this search were used to create the conflict, since many names, about 4000, of women scientists were encountered during this quest. These names stretched from antiquity to the 21 century. The results of this intervention were discussed and the conflict was defined: in contrary to the initial assumptions found in the pre test, thousands of names of woman scientists were encountered. Name lists contained scientists of varying domains: Astronomy (starting from antiquity during the renaissance and modern astronomers); Physics (Nuclear physics); Biology (Molecular biology); and applied science (solar energy). Among them domains which the participants thought that will not include women at all, such as physics, astrophysics, and molecular biology. This encounter was commented by the students: "I did not know about women scientists and now I learned about so many of them". "Doing this search I discovered so many women scientists and in so many domains", "I will try to include women scientists in my lessons". The new findings motivated them to learn more about women scientists, particularly in these domains that were considered as not including women.

\subsubsection{Extending}

The students continued their learning about the women scientists by carrying out in depth investigation of women scientists or groups of women scientists, according to their free choice (Table 1). This work was done in groups of four students each investigated the domain of its group particular choice. The projects were summarized as learning units for their pupils. The results of each research project were introduced to the whole group through lectures and Poster presentations. These in depth study projects were carried out through the use of books, films, internet investigation, and meeting with acting scientists of the domains chosen to be studied by the groups. The preparation of the learning units on science and scientists was videoed in all the stages of collecting the data, writing the leaning materials, presenting the project to the group and teaching it. The participants presented the units to the whole group. They followed their work by writing a diary reflecting on their work. Presentations were followed by student's own written journals. Opinions were exchanged between the student's and the student's teacher to evaluate their writings. Details about the projects are given in Table 1.

Table 1. description of projects and their evaluation

\begin{tabular}{|c|c|c|c|c|}
\hline Discipline, and Domain & Women Scientists & For grade & Learning Material & Graded \\
\hline $\begin{array}{c}\text { Biology: } \\
\text { Primathology }\end{array}$ & $\begin{array}{l}\text { J. Goodall } \\
\text { D. Possay }\end{array}$ & Seven & Frontal Learning Center & good \\
\hline $\begin{array}{c}\text { Physics: } \\
\text { Radioactivity }\end{array}$ & $\begin{array}{l}\text { M. Curie } \\
\text { I. J. Curie } \\
\text { P. Curie } \\
\text { L. Meitner }\end{array}$ & Nine-Ten & Learning Center & good \\
\hline Astronomy and Stars & $\begin{array}{l}\text { H. S. Leavitt } \\
\text { A. J. Cannon } \\
\text { W. Fleming } \\
\text { C. P. Gapocshkin } \\
\end{array}$ & Eight -Nine & Learning Center & Average \\
\hline Biology: Different Domains & $\begin{array}{l}\text { D. Possay } \\
\text { R, Franklin } \\
\text { L. Thors. }\end{array}$ & Nine & Frontal Learning Center & Average \\
\hline Medicine: Aids & $\begin{array}{l}\text { F. Wang } \\
\text { R. Galo }\end{array}$ & Nine & Frontal & Low Average \\
\hline
\end{tabular}

Table 1 contains the interesting names of women who investigated apes, domains considered as un fit for women, such as molecular biologist Rosalind Franklin, and aids found also as chosen domains of women by [4] and [2]. The participants presented the units to the group at the beginning and at the end of the research and got reflection from it. The students followed their work by writing a diary reflecting on their work.

\subsection{Projects and their Evaluation}

The projects were evaluated through video and audio documentation of parts of the groups' work, mostly made when the students discussed their principles for constructing the units, and the students written diaries reflecting on their work. Citations from the students were drowning from these sources. The above mentioned assays: "Day in a women scientist life" was part of the projects' evaluation. Learning units were evaluated according to the accepted evaluation criteria of academic works [1].

\subsection{Student Products}

Three projects were chosen here for more detailed description. Two of them were domains that were considered by the participants, at the pre test stage, as unfit for women, domains that would not contain women scientists: nuclear physics and astrophysics. The students were surprised to discover through the web search the significant contribution of women to those domains and others; and decided to follow the ideas of those women. The third described project was the ape research [6] that had a profound effect on the students' view on science and on their self image as women scientist as reflected in their post test assay.

\subsubsection{The women that Contributed to the Beginnings of the Research of Radioactivity}

This domain is related to nuclear Physics, and contains the beginning of the investigation of radio activity. It was chosen by the group since most participants said, before the intervention, that they think that women did not contribute to Physics in general, and to Nuclear Physics particularly. This was said in spite of the fact that the only woman's name that appeared in many groups' name lists (but only once or twice in each of them, 1, 2) was the one of Marie Curie. The intervention chosen was meeting with the educational staff of a small nearby research reactor. During these meetings the participants discovered the real contribution of Marie Curie to the measurement of the rate radioactive reactions, and her discovery of new radioactive elements. Those discussions revealed also the name of the daughter of Marie Curie, Irene Joliot Curie 
and her contribution to Physics, in the form of the discovery of inspired (artificial) Radio Activity; and the name of Lise Meitner, who suggested a model to divide the Uranium Nucleus (through fission). Thus the names of three women that pioneered this domain were learned. In their report the students defined this project as belonging to Physics, which many of them thought that women never contributed to. This intervention was followed by learning about the domain from popular science books. The report of the project included also the need to be aware of the dangers of the use of Reactors, and the possible safe uses of them, as they were described in Scientific American; this and other problems concerning this domain were then discussed by the participants.

\subsubsection{The Dawn of Astrophysics}

This project is connected to a special group of women scientists. These women were not accepted at the University of Harvard only to the women college. They were not allowed to work at the observatory, since it was considered unfit for a woman to work alone at night and with men. They were only allowed to do compilation work, to decipher spectral lines of stars' spectra, taken by the observers that worked, in various places of the world like Chilly (a new installed observatory at the time). They considered themselves as real scientists following the tradition of F. Beckon (philosopher that presented the experimental inductive approach to science investigation). Their assignment was to collect the data and measure the wave lengths in the spectra of the observed stars line after line. This was an enormous work that needed patience and accuracy; women showed that they were better than men in doing it. This remark made by the leader of the group motivated our students to re think their role as scientists. During this work some names of this group's members stuck out. The students concentrated on three of them

\subsubsection{Annie J. Canon}

While investigating wave lengths of stellar spectra, Annie Canon discovered that stars with different colors (temperatures) contain different spectral lines. Findings this she identified the spectral types of the stars. Her classification method and scheme hold till today.

\subsubsection{Henrietta S. Leavitt}

While working on changing stars, Henrietta Leavitt found that there is a relationship between the star's luminosity and its period. Since the periods of change of the luminosity of distant stars could be, and were measured, the distances of those stars could be calculated. Her finding paved the way to a new method to measure distances of stars that had a major influence on the realization of the construction of our Galaxy, and on the evolving of the new Cosmology.

\subsubsection{Cecilia Payne-Gaposchkin}

This scientist claimed that though we see many metal lines in the sun's photosphere spectrum, it does not mean that the sun is made mostly of metals; instead she suggested that it is mainly made of Hydrogen and Helium (based on arguments of the sun's mass and dimensions). This idea was not accepted by the scientists' community since she was a woman, in Harvard she was suggested the position of a calculator, like the other women. Her luck was that the leader of the observatory Prof. Harlow Shapley acknowledged her ideas, and accepted her as a mate professor. Later when he retired she got his position.
One of our students commented that: "reading about women scientists is her hobby," which "makes her appreciate their merits and difficulties".

While carrying out this project the students met three magnificent women scientists who were the pioneers of modern Astrophysics: 1. taught us how to classify stars a work that paved the way to learn about their structure and development. 2. Found a new way to measure distances of stars. 3. Confirmed the correct elemental consistence of sun and stars. The students learned how these women over came their difficulties and did their ingenious work. In contrary to the pre test a student summed up: "now I am convinced that women work in astronomy, considered as male domain". This encounter motivated the participants of the project to visit the nearby planetarium and observatory, and then some of them joined a study group in astronomy.

\subsection{Primate Investigation}

This investigation focused on Jane Goodall and Dian Fossey, reading their books, and observing films about them. Some students knew the names of those women investigators before, but the knowledge was shallow and diffused. They did not know who investigated the Gorillas and who investigated the Chimpanzee. The students were not aware of the methods used by these investigators. The interventions (in the form of books and movies) lead to more precise knowledge about each of the women primate investigators. Through those research studies the students encountered a different method of investigation from the one described by them in the pre test: an investigation based on observation, involvement with the subjects (the primates): imitating them, using audio and video recording of their appearance and behavior. An investigation based on concern and empathy for its subjects and the environment. Ape Research contained getting close to the animals, and learning the meaning of their voices and body language. To get insight to this kind of research the students met with a woman who raises a monkey in her home as a pet. This gave them an opportunity to watch a monkey, to see his behavior and how he looks like. They were impressed and fascinated by his cleverness, and the way he resembles a human being. To get more acquaintance with the field, the group visited the Z00 and the Safari, observed the real animals and watched their behavior. All this knowledge featured it their report. Such experiences might influence social involvement about animal rights initiated lately in our country.

The students learned about the difficulties these researchers encountered. Difficulties that initiated from society criticisms of women working, alone in the wild, governments' resistance to their work, poachers, and the difficulties of the work itself: how to get close to the researched animals, and how to make sense of their behavior and their motives. One of our research groups that contained religious students resisted the idea of women's working in the wild: "It will harm her family" [2].

A discussion about the motivation of the researchers to pick up this domain, in spite of all its hardships, was carried out. The students motivated by the Movie, attributed this motivation to willing to take care of nature and avoid the distinction of the animals. Other student (Female) mentioned that the resemblance of these animals 
to humans, their being affectionate to their family, and their complicated behavioral patterns within their community and family, motivated the researchers to carry out research in this domain. One said: "It is more involving than physics that deals with cold instruments and ideas". Students who did not choose this project also became involved in it through film observing and discussions.

These are descriptions of some projects that students choose to do. In the next passage we will show how the encounter with the new information and acting scientists while doing these projects changed their ideas about women scientists, and science in general. The Internet intervention presented the knowledge that there are many examples of women scientists starting from antiquity up till today was the motivating trigger for the further learning and research. The projects gave the students the opportunity to enter deeply to the understanding of works of some of the scientists. The domains of the projects are not parts of the curriculum; students were introduced to new modern and interesting domains of science.

\section{Conceptual Change}

\subsection{Pre-Intervention Understandings}

The results of DAST, five names, and sources of knowledge were similar to those of previous studies; results pointed at minor reference to women scientists, field work (mainly in religious group) and teamwork, use of conventional equipment. Pre-intervention views revealed a masculine image of science. Scientists were viewed as knowledgeable, intelligent, clever, methodic, accurate, diligent, stubborn and competitive, working lonely in the lab for many hours using bottles and test tubes,. The participants defined those characteristics as male properties, similar to [5,21]. Even the caricaturist description of having disheveled hair and untidy dress appeared in this group as in many others: "the un apt socially not functioning male with the goggles and labcoat" was repeated.

At the pre test stage only $6 \%$ of the participants answered affirmatively that they could be a scientists or wanted to be one. This is not astonishing since these students decided not to become scientists, as they chose another occupation, what is more interesting are the justifications that they give for their decision not to choose science in the first place. The student indicated, "I am not willing to be a scientist, scientists are lonely, they are not friendly, they work alone in the lab; they also do not pay attention to their family". "Scientists need strong will power and patient, they need to be perfectionist and very intelligent, interested only in science and reading". "They do not contribute to society" and "are interested only in their science". These reasons should be checked and explained, description of scientist as having only a few connections, is related to them being asocial was found also through the other tools such as properties. Taking care of the family is attributed to women; this feature is regarded to be very important in our society. Students said that the long hours needed for the scientists' work harms the family: "I prefer to be a mother and not work all the time". The note concerning the bad influence on the family life is quite unique to this tool. The noted properties that define the scientist appeared also in this tool. These properties were regarded by the groups as men's properties, students said: "I am not stubborn enough" "I am not competitive enough". Other properties as intelligence, diligence being methodic and accurate, were also defined in free answers as typical to men. A reason given, by both men and women is: "the scientist needs to read many boring articles", those who give these answer do not realize that this reading material that seems to them boring, is regarded by the scientist as interesting since it gave him/her new knowledge and insight for his/her work. As for contribution to the society the participants understand it as helping the poor, doing volunteer work, giving money to charity or, as in [22], as being a physician who has direct connections with people and cures their ailments. The reason for this view initiates clearly from lack of knowledge about the role of science in improving human life, and the high amount of research that goes into medicine, and other sciences, in the form of new tools, processes, diagnostic, and medicines. The effect of meeting with acting scientists on these opinions was checked through the involvement experience.

Students thought that scientist work was done in a closed space and alone, which initiated negative reaction toward the scientist work. Repeating results from other tools: the scientist only carried out experimental work, and dealt with instruments, a picture of the scientific work that seems to the participants opposite to being a woman. As found by [4] women tend to prefer occupations that deal with human being or animals upon using equipment, working mainly in the Lab. Thus pre-project views were summarized by: "being a scientist does not fit the woman personality". Drawing and captions show women scientists as tom between family and work, a Super Scientist.

\subsection{A Day in a Scientist's Life}

The essays were written before and after the intervention that included the preparation of the learning materials. Students were asked to write about a day in the life of a man and a woman scientist. The content of these assays were analyzed by using the normative method [23] to analyze the content according to pre defined categories. These categories were inductively devised from the findings of the other tools of the research and from the texts of the assays themselves about men and women scientists. The analysis will be accompanied by citation from the assays.

\subsubsection{Schedule}

"The man scientist is perfectionist. Most of his daily hours are dedicated to his work he does not put limit to his work". "His work does not start nor does it end at a given hour," "The research is the center of his life". "He gets up at 7 o' clock, reads scientific papers stays in the lab for 10 and even 11 hours. Since he is much occupied in his work he eats only sandwiches. "He continues to work at home reading and collecting data from the internet and writing papers." "The women scientist arrives to her work after bringing her children to school. At lunch time she has an intermission, and at about four o'clock in the afternoon she leaves her work and goes home to attend to her family." "Before going to work she brings the children to 
kindergarten and school". "About four in the afternoon she brings them home and spends time with them until they are asleep. Then she has some time to read papers".

These captions show the differences in the schedules of the man and the woman scientists. Experience from the other tools confirms these descriptions. The male scientist is dedicated to his work and is absorbed only by it; woman scientist has to divide her time between work and family chores. Described as "Super woman", torn between family and work; a Super Scientist (Figure 1) a view supported by information from drawing and their captions.

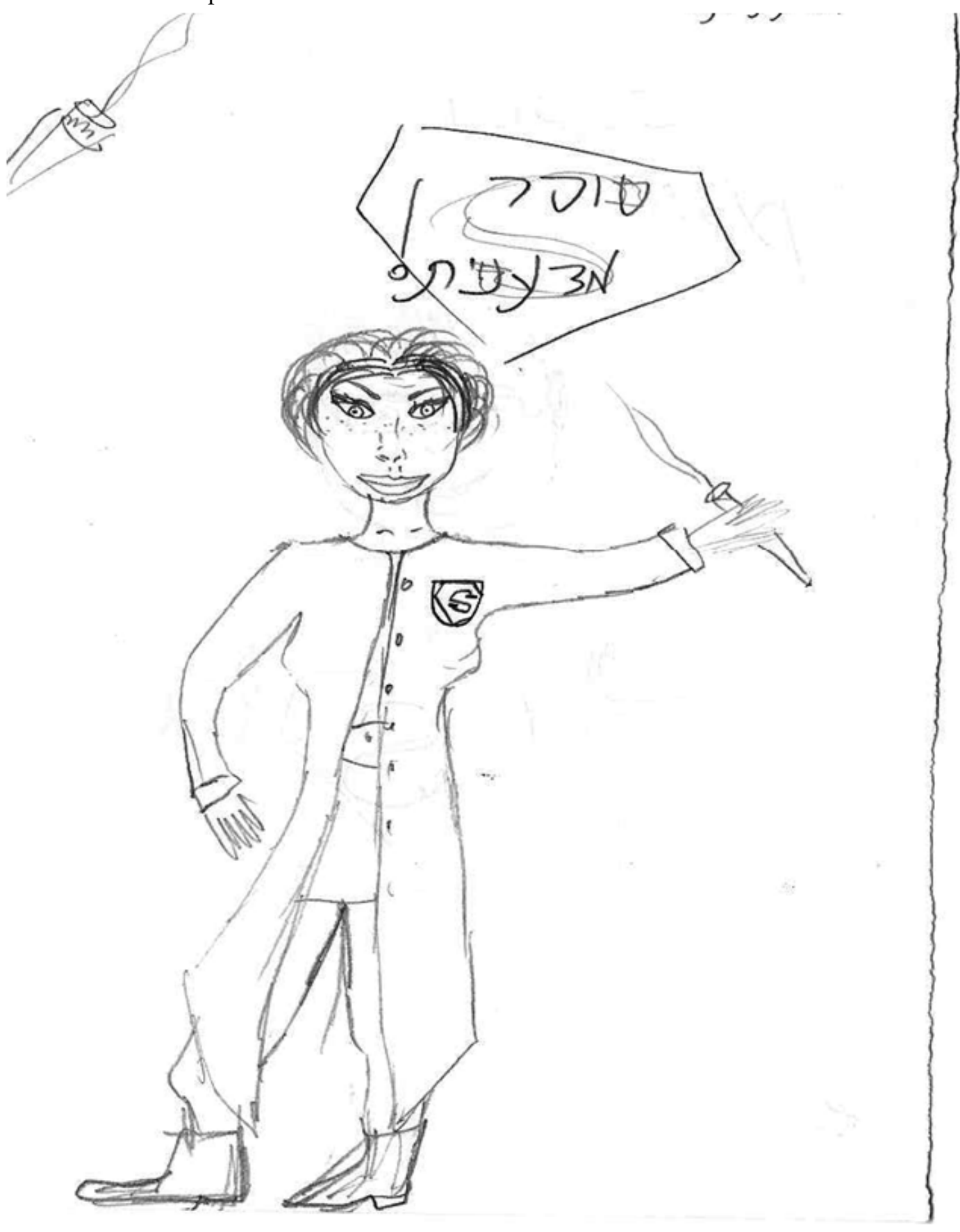

Figure 1. Drawing of women scientist pictured as a super women to signify her hard work.

\subsubsection{Age and Appearance}

The participants viewed scientists as being about 50 years old, the woman is described as younger and strict about her appearance, nicely dressed and keep fit:

"Scientist is 50 years old, dressed with old shirt and sport shoes that do not fit him". "He is untidy, most of the time looks lost with his spectacles that always fall on the edge of his nose, and his lab robe big for his skinny body". Whereas: "She looks good, about 40, nicely dressed. Before starting her work she puts off her jewelry and wears gloves", also [6]. "She, on the contrary, has nice short hair cut; she is very nice, and nicely dressed, a very impressive woman". These descriptions fit DAST results. Male descriptions are similar to those of [25]. The male scientist represents the stereotypic image found in the previous research. The female scientist is an idealized image stressing her need to be "woman": elegant, young, nice looking [6].

\subsubsection{Social Life}

Male scientist has limited social and family connections; performs his work alone: "He is dedicated to his work does not consider family and friends not even himself as he is so dedicated to his work". Male scientist is 
authoritarian: "He starts his day walking with his wife in the neighborhood this is the only time they spend together and speak about house hold affairs. He sees his children when they are already asleep, he talks with them during meals only; on Saturday (day of vacation) he plans a trip with them. With his mates he talks shortly and also in team meetings he only asks them for helping his work". The description reflects loneliness, dedication and being authoritative.

Female scientist has warm and close connection with friends and family: "good connections with relatives and friends. Sometimes visit them or accept them in her home". Takes care of her family and as was stated by [4]: "woman prefers to work with people (or animals) rather than experimenting and using tools". "She is a good and kind woman smiling and laughing, has hobbies like ceramics and exercising, meets friends, likes to travel with family and visit relatives". These descriptions complement previous descriptions of the scientists like the scientist properties and answers to the question about willing to be scientist. Scientist is lonely, does not need nor does not wish to consider other people, not even his family. Woman scientist has family obligations and social connections. Over emphasis on family connections is typical to Israeli culture. These descriptions reflect stereotypes about both male and female

\subsubsection{Place of Work}

Both male and female are described as working in the lab: "It is a fact that all scientists work in the lab"; "this crazy scientist always works in the lab". Both are immersed in work doing experiments reading papers connected to their work. "He is immersed in experiments to analyze the new medicine mixing many quantities of materials in many vessels to reach the best result" description is similar to the try and error [6]. Scientist described as an experimentalist and inventor, fit

Table 2. changes in the image of the woman scientist secular group, between pre to post test. The number of times each item was mentioned is given in percentages

\begin{tabular}{|c|c|c|c|}
\hline Categories & Variables & Before & After \\
\hline \multirow[b]{2}{*}{ Physical characteristic } & Age & About 40 & About 40 \\
\hline & $\begin{array}{c}\text { Dress: } \\
\text { fashionable } \\
\text { untidy }\end{array}$ & $\begin{array}{c}95 \\
0\end{array}$ & $\begin{array}{c}75 \\
5\end{array}$ \\
\hline \multirow{7}{*}{ Place and type of work } & In the lab & 95 & 55 \\
\hline & Field work & 0 & 45 \\
\hline & Experimenting & 95 & 65 \\
\hline & Reading writing & 20 & 45 \\
\hline & Team work & 20 & 35 \\
\hline & Using computer & 5 & 65 \\
\hline & Long hours & 20 & 35 \\
\hline \multirow{3}{*}{ Out of work occupation } & With family & 100 & 80 \\
\hline & Working at home & 70 & 80 \\
\hline & Hobbies and friends & 40 & 40 \\
\hline \multirow{2}{*}{ Relationships in family } & Minimal & 0 & 0 \\
\hline & Maximal & 100 & 70 \\
\hline \multirow{2}{*}{ Typical properties } & Dedication to work & 50 & 70 \\
\hline & Tom between work and home & 50 & 25 \\
\hline
\end{tabular}

According to Table 2 the work of the scientist is not solely experimenting in the lab, it includes reading, writing, and teaching. Assays commented: "The scientist is interested in her students and helps them in their work"; thus adding team work to her work. Including team work was influenced by the meetings with the scientists, and the fact that the projects were done by teams, which most students found useful as apparent from their remarks: "I liked team work; it gives an opportunity to change views and encounter difficulties". Field work is mentioned: "in descriptions of science and scientists among pupils in England [16]. Scientist as remote and lonely was given in [22] and [23]. Scientists as merely experimentalists do not fit the theoreticians' first names in the scientists' name list. This mostly experimental science fits modern approach to science as "science technology" [3].

The views of the students that took part in the project found in the pre test stage together with previous findings were exposed to the participants. The students confronted with the information, about the findings reflected upon them. Results pointed at very little reference to women $[3,5,6]$ : "it is obvious that there are no women scientists I never met one". Being women themselves (19 out of 20) the participants wanted to check this point. Other deficiencies that appeared in this reflection were low reference to field work, loneliness and limited old fashioned equipment [6]. Project involvement affected also these deficiencies (see projects section).

\subsection{Post Intervention Understandings}

After the intervention, more drawings of women existed; name lists contained more examples of women names, taken from the projects and the internet. Encounter with field work, carried out mainly in the ape project, when some other projects presented combination of field and laboratory experimental work enhanced this aspect. The attitude towards science changed students said that science is interesting. The properties of the scientist were similar to those of the pretest, but free oral expression contained other properties like enthusiastic interest, compassion, care for extinct species and environment and motivation some of which are typical to women.

The change between pre and post test is reflected in Table 2 and in free writing: "a day in a women scientist life" according to [24]. some days she experiments and in others she collects samples in the field"; "her work is about insects that alive under stones, she collects samples of them to analyze in the lab". Scientific work is described here as related to a specific domain, at the pre stage it was general and unspecified "he does experiments". There was some increase the of the women scientist dedication for work while nice appearance is still perceived as important (75\%). The gap-between home and work is less mentioned. The interventions showed to the students that some work 
typical to the activities done in the teacher college can be regarded as part of scientific research, a fact also mentioned in [6]: "we did some activities related to nature in school, but did not consider them as science". This consideration was more emphasized at the post stage essays when collecting samples of plants and insects in the field was incorporated in some projects (also 6). Descriptions of the work of the scientist are much more detailed and concrete than in the pre-stage. Assays show the woman scientist as more relaxed, cooperating in team work; her students also collaborate in her work. They perform some research assignments related to her work. Team work is done also in the lab: "she works together with other seven mates". Sharing her research with team mates and students, leave her more time to investigate the web-net, read, and share time with her family. Team work with coworkers and mates was mentioned and appreciated; together with connections with other scientists as use of Mail to get more information. Percentages of computers increased considerably (Table 2 and drawings). Getting information from the computer is described as a regular part of her work at the post test stage. Except the computer Woman scientist uses other sources of information as consulting with specialists and attending meetings. More elaborate equipment special to the research domain is included (such as: a telescope, video camera, and microscope). The essays proved that the attitudes of the teacher students towards women scientists changed. The scientist is described by them as more relaxed: "Taking Coffey with her colleges", "she takes lunch break". The idea of becoming a woman scientist became more appealing for the students percentages of those who would like to participate in research increased (12\%). Other aspects that were missing from previous research and pre stage of this research appeared in this stage, such as field (out of class) work, use of more sophisticated and special equipment. This shows that being involved in an active project about women scientists also corrected other deficient aspects of the scientists' image making it wider, more interesting relaxed, and at the same time more specific and focused. Many aspects of the involvement are replicated in the post stage documentation: computers and other more sophisticated equipment, team work, consulting with experts. Use of Telecommunication, media, internet and traveling that open up for meetings between cultures [4], leading to exchange and diffusion of cultural traditions, perceptions and belief were found in the post stage. "More information is being created and new media and communication systems make updated information instantly available" (the same), make choices more knowledgeable.

\section{Conclusion}

Prior to intervention, the group of pre-service teachers from Israel showed stereotypical images similar to those in other researched groups $[2,3,5,6,11]$. The image of the scientist was deficient in several aspects: almost no women names were mentioned, there were only limited references to field work, the equipment used was restricted to conventional equipment similar to school's equipment, only few references were made to teamwork. The intervention surfaced the students to the existence of women scientists, from antiquity and up to the present $21^{\text {st }}$ century (about 4000 names were counted). Encountering so many women names motivated the students to search for more information, in the form of an inquest project that consisted of getting information from media, movies and books, and meeting with acting scientists (in the Observatory, the Reactor, the Zoo, and in other places). Parts of projects related to scientists that work in the field resulted in including field research in our student's reports. Doing the projects and meeting with acting scientists inspired students to include more elaborate equipment in their reports. Special aspects of some projects such as the emphasis of the compatibility of women to research stars' spectra; the special motivation and methods used in the primates' research made the students (women) closer to science.

Some projects were not finished successfully, but the effort to do them helped to change the attitudes towards women scientists, which made the images of them more relaxed. Doing the projects pointed also to a change concerning other missing aspects in the scientist's description, found in the pre test. At the post test we could identify the inclusion of field work, diversification of the equipment, using the media and doing team work. Projects inspired the students to engage in further learning.

In order to get a change in the students' view of the scientist image, a set of actions of intervention was made aimed at creating a new conception toward it. The results of this effort are mirrored in their post investigation essays, where woman scientist is imaged as less stressed, more confident, less lonely (sharing with colleagues and students). These changes point at more positive attitudes towards being women scientists among the teacher students. This change occurred among our students and can also occur among the pupils, whom they will inspire: "I will include women scientists in my teaching". The new image of the woman scientist is related to her identity as a woman such as the wish to relate to people: "I can do work with the computer, but not all the time, I need to meet with people and discuss with them. The preference of the woman scientist is, according to the students "is to work with people and animals" [4]. The properties of the scientist are still described as being intelligent, diligent, methodic and accurate. But, to this list other properties were added: compassion to the research subjects: Gorillas and chimpanzees, caring for extinct species, caring for the environment. reflected in their reports: "she supports a center for caring about the quality of the environment". Learning about researchers that dealt with animal behavior opened our participants to the possibility of conducting research based mainly on involvement with research subjects: getting in contact with them, imitating them, when most of the research is done by observation using binoculars and recording the behavior. The students' view of the scientific method became more general as reflected in the post test results. Intensified and accelerated communications systems typical to our period encouraged the use of computers and other media sources. The list of properties and research methods became more extended than the definition of $[25,26,27]$ the western scientist and science that alienated our students. Within two research programs we described recently the changed image of the scientists and the scientist work among pre service science teacher students due to intervention: [6] and the present 
research. In the present research carried out in Israel community the limitations of traditional society were mentioned. A high concern of the woman for the family and house hold chores were emphasized in both traditional and secular populations. Stressed resistance against field work far from home was found among traditional religious students. The scientist man has no limitations he is highly dedicated to his work outside of home and in it. Man scientist is solitary and authoritative. Both research emphasized active involvement as a way to conceptual change.

\section{References}

[1] Rubin, E., Bar, V. And Cohen, A. (2003). The images of Scientists and Science among Hebrew and Arabic speaking pre-service teachers in Israel. International Journal of Science Education, 25 (1), 35-48.

[2] Koren, P., \& Bar, V. (2009). Pupils' image of 'The scientist' among two communities in Israel: A comparative study. International Journal of science education, 31 (18), 2485-2509.

[3] Scherz, Z and Oren, M. 2006. How to change students' images of science and technology. Science education, 90 (6), (965-985).

[4] Schriener C. (2006). Exploring a Rose -Garden Norwegian youth's orientations towards science- seen as signs of late modern identities. Dissertation, University of Oslo.

[5] Buck G., Koren P., Yin X., Bar V 2011. Reframing Non-Science Majors' Fundamental Understandings about Scientific Inquiry and Scientist, submitted for publications.

[6] Buck, G. Vicki L. Plano C. Diandra L. Yun L., Cerda-Lizarraga P. 2008, Examining the cognitive processes used by adolescent girls and women scientists in identifying science role models: A feminist approach. Science Education Volume 92, Issue 4, pages 688-707.

[7] Scardemalia, M. and Bereiter., C. (1986) Research on written composition. in Wittrock, M., (eds.), Handbook of Research on Teaching (New York: Macmillan Education.) pp.

[8] Trankina, M. L. (1993) Gender differences in attitudes toward science. Psychological Reports, 73, 123-130.

[9] Abd-El-Khalick, F. \& Lederman, N. G. (2000). The influence of history of science courses on students' views of nature of science. Journal of Research in Science Teaching, 37, 1057-1095.

[10] Lederman, J., \& Lederman, N. (2005). Developing and assessing elementary teachers' and students' understandings of nature of science and scientific inquiry. Paper presented at the Annual Meeting of the National Association for Research in Science Teaching, Dallas, TX, April, 2005.
[11] Kuhn T. (2000). The structure of the scientific revolution. Chicago press.

[12] Beck U. \& Beck-Gernsheim, E. (2002). Individualization. London: SAGE, Publications Ltd.

[13] Sjoberg, S. and Imsen, G. (1998) Gender and science education. in Fensham, P., (eds.), Development and dillemmas in science education (London: The Falmer Press) pp. 218-248.

[14] Turkmen, H. (2008). Turkish primary students' perceptions about scientist and what Factors affecting the image of the scientists. Eurasia Journal of Mathematics, Science and Technology Education, 4 (1), 55-61.

[15] Cakmakci, G., Tosun, O., Turgut S., Orenler, S., Sengul, K., \& Top, G. (2010) Promoting an inclusive image of scientists among students: Towards research evidence-based practice. International Journal of Science and Mathematics Education.

[16] Driver, R. and Oldham, V. (1986) A Constructivist Approach to Curriculum Development in Science. Studies in Science Education, 13, 105-122.

[17] Nusbaum and Novik, (1985)) The particulate nature of matter in the gaesous phase. in al., D. E., (eds.), Children ideas in science Milton Keynes: Open University Press).

[18] Kedem, O. (1999) Temporarily Definitive. Ph.D. thesis (Salford: University of Salford)

[19] Newton, L. D. and Newton, D. P. (1998) Primary childrens' perceptions of science and the scientist: is the impact of National Curriculum breaking down the stereotype? International Journal of Science Education, 20, 1137-1149.

[20] Solomon et al. 1996 Solomon, J., Scott, L. and Duveen, J. (1996) Large scale exploration of pupils' understanding of the nature of science. Science Education, 80 (5), 493-508.

[21] Rampal, A. (1992) Images of Science and Scientists: A study of school teachers' views. I Characteristics of scientists. Science Education, 76 (4), 415-436.

[22] Steffanson K. K. (2006). 'I just don't think it’s me': A study on the willingness of Icelandic learners to engage in science related issues. Master thesis, University of Oslo, Faculty of Education, Department of Teacher Education and School Development, Oslo.

[23] Miles, M. B. and Huberman, P. M. (1994). Drawing valid meaning from qualitative data: Toward a shared craft. Educational Researcher, 13 (5), 20-30.

[24] Finson, K. D., Beaver, J. B., \& Cramond, B. (1995). Development and field test of a checklist for draw-a-scientist test. School Science and Mathematics, 95(4), 195-205.

[25] Sagan, C. (1995).the demon-haunted world: science as a candle in the dark. new york: Random House.

[26] Aikenhead, G. (1987) High school graduates' beliefs about science-technology-society. 3: Characteristics and limitations of science knowledge. Science Education, 71 (4), 459-487.

[27] Aikenhead, G. (1996) Science Education: Border Crossing into the Subculture of Science Studies in Science Education, vol. 27 pp. 152. 